\title{
Evapotranspiration and water sensitivity of Amazonian yellow ipe seedlings under different shading conditions
}

\author{
Josiane F. Keffer ${ }^{1}$, Cátia C. da Silva ${ }^{1}$, Adilson P. de Souza ${ }^{2}$, Andréa C. da Silva², \\ Luana Bouvié ${ }^{2} \&$ Thaíse K. R. Dias ${ }^{1}$

\begin{abstract}
${ }^{1}$ Universidade Federal de Mato Grosso/Institute of Humanities, Natural and Social Sciences. Sinop, MT, Brasil. E-mail: kefferjf@gmail.com - ORCID: 0000-0001-6134-7372; catiasilvaflorestal@gmail.com - ORCID: 0000-0002-1079-8728; thaiserdias@yahoo.com.br - ORCID: 0000-0001-7047-8550

${ }^{2}$ Universidade Federal de Mato Grosso/Institute of Agricultural and Environmental Sciences. Sinop, MT, Brasil. E-mail: pachecoufmt@gmail.com (Corresponding author) - ORCID: 0000-0003-4076-1093; andcar1007@gmail.com - ORCID: 0000-0003-2921-3379; bouvieluana@gmail.com - ORCID: 0000-0003-1884-934
\end{abstract}

\begin{abstract}
The scarcity of information on the agroclimatic and ecophysiological requirements of forest species, especially in the initial phase, limits the production of quality seedlings, the planning and optimization of nurseries. The potential evapotranspiration, crop coefficients (kc) and water sensitivity coefficients (ky) of Amazonian yellow ipe seedlings were determined under different shading conditions and levels of water replacement to the substrate, in the dry period (July to October 2016), in the Cerrado-Amazon Rainforest transition region of the Mato Grosso state, Brazil. The experiment evaluated the full sun and black polyester nets with 35,50, 65 and $80 \%$ shading, and the levels of water replacement to the substrate of $25,50,75$ and $100 \%$ ETc in a split-plot scheme, with irrigation fractions established according to the maximum water retention capacity of the substrate. The water consumption of Amazonian yellow ipe was 239.2, 228.6, 204.1, 185.7 and $136.3 \mathrm{~mm}$ for cultivation under full sun and shading levels of 35, 50, 65 and $80 \%$, respectively. The daily means of ETc were $3.37,3.22,2.87,2.61$ and $1.92 \mathrm{~mm} \mathrm{~d}^{-1}$, whereas the kc means were 1.13, 1.15, 1.05, 0.90 and 0.60 for the above-mentioned shading levels. ky values ranged from 0.89 to 1.28 , with reduction due to the increase of water replacement and increase for higher shading percentage.
\end{abstract}

Key words: Handroanthus serratifolius, crop coefficients, water deficit, irrigation management

\section{Evapotranspiração e sensibilidade hídrica de mudas de ipê-amarelo amazônico em diferentes condições de sombreamento}

RESUMO: A falta de informações técnicas sobre as exigências agroclimáticas e ecofisiológicas de espécies florestais, principalmente na fase inicial, limitam a produção de mudas de qualidade, o planejamento e a otimização de viveiros. Determinou-se a evapotranspiração, coeficientes de cultivo (kc) e os fatores de sensibilidade hídrica (ky) de mudas de ipê-amarelo amazônico em diferentes condições de sombreamento e níveis de reposição de água no subtrato, no período seco (julho a outubro de 2016), na região de transição Cerrado-Amazônia de Mato Grosso. O experimento avaliou os níveis de sombreamento em pleno sol e com telas poliefinas pretas de 35,50, 65 e $80 \%$ de sombreamento, e os níveis de reposição hídrica no substrato de 25, 50, 75 e 100\% da ETc, com fracionamentos de rega estabelecidos em função da capacidade máxima de retenção de água do substrato em esquema de parcelas subdivididas. O consumo de água do ipê-amarelo amazônico foi de 239,2; 228,6;204,1; 185,7 e 136,3 mm para as condições de pleno sol e sombreamentos de $35,50,65$ e $80 \%$, respectivamente. A ETc média foi de 3,$37 ; 3,22 ; 2,87 ; 2,61$ e $1,92 \mathrm{~mm} \mathrm{~d}^{-1}$, enquanto que os valores de kc foram 1,$13 ; 1,15 ; 1,05 ; 0,90$ e 0,60 para os níveis de sombreamento supracitados. Os valores de ky variaram de 0,89 a 1,28, com redução pelo aumento da reposição hídrica e aumento para maiores percentuais de sombreamento.

Palavras-chave: Handroanthus serratifolius, coeficientes de cultivo, déficit hídrico, manejo de irrigação 


\section{INTRODUCTION}

The Amazonian yellow ipe [Handroanthus serratifolius (Vahl) S. O. Grose] is a forest species native to South America, classified as secondary and occurring in several Brazilian phytogeographic domains (Ferreira et al., 2004; Grose \& Olmstead, 2007). It is widely planted in urban areas and with potential for use in reforestation and recovery of degraded areas (Fávero et al., 2008).

In forest nurseries, in the initial stage of seedling development, the availability of water and the intensity/ quality of incident radiation stand out as limiting factors for plant growth and development, because, depending on their interactions, errors can occur in the dimensioning and/or water management, with reduction of potential yields of the species, establishment of diseases, increase in the consumption of nutrients, water and energy, reduction of the germination potential and homogeneity in seedling development (Oliveira \& Perez, 2012; Monteiro et al., 2016).

Evapotranspiration allows defining the water requirement of a crop according to the interactions and dynamics of water movement in the soil (substrate)-plant-atmosphere system. Among the various concepts and forms of determination, crop evapotranspiration (ETc) indicates a condition in which a vegetated surface can express its maximum productive potential (genetic), with no water, nutritional and phytosanitary constraints (Allen et al., 1998).

Defining the response factors of the crop to water deficit (ky) allows indicating in which period of the plant life cycle (phenological stage) there is greater sensitivity to water stress (Doorenbos \& Kassam, 1979). Therefore, ky constitutes an important tool for rational water management in forest nurseries, because there are no changes in the phenological stages in the seedlings (only vegetative stage), thus allowing the optimization of water use according to the requirements of each species (Silva et al., 2014; Santos et al., 2017).

This study aimed to determine the evapotranspiration (ETc), crop coefficients $(\mathrm{kc})$ and water sensitivity factors (ky) of Amazonian yellow ipe seedlings, under different shading conditions, in the dry period of the Cerrado-Amazon Rainforest transition region of Mato Grosso state, Brazil.

\section{Material ANd Methods}

The experiment was conducted between June and October 2016 , in the municipality of Sinop, MT, Brazil ( $11.85^{\circ} \mathrm{S}$ and $55.38^{\circ} \mathrm{W}$ and altitude of $371 \mathrm{~m}$ ). According to Köppen's classification, the climate of the region is Aw (hot and humid tropical), with two well-defined seasons: rainy (October to April) and dry (May to September), with annual average precipitation and potential evapotranspiration of 1974.77 and $1327.29 \mathrm{~mm}$, respectively, and monthly average temperatures between 23.2 and $25.8^{\circ} \mathrm{C}$ (Souza et al., 2013).

The seeds of Amazonian yellow ipe [Handroanthus serratifolius (Vahl) S.O. Grose] were germinated in chambers with constant temperature of $30{ }^{\circ} \mathrm{C}$ and $12 \mathrm{~h}$ photoperiod, where they remained until the appearance of primary roots and cotyledon leaves. Subsequently, the seedlings were kept for 25 days on polystyrene trays ( 124 cells), containing commercial substrate made of coconut fiber. Upon the emergence of the first pair of true leaves and root system establishment, the seedlings were transplanted to $290 \mathrm{~cm}^{3}$ tubes on July 20, 2016 . The substrate used consisted of a mixture of $75 \%$ forest soil Oxisol and 25\% carbonized rice husk, with incorporation of $2.0 \mathrm{~g}$ of NPK (5-30-15) fertilizer per tube, promoting a density of $0.578 \mathrm{~g} \mathrm{~cm}^{-3}$. Water retention capacity (WRC) was obtained considering the mass of the tubes with the seedlings after saturation and free drainage of water (saturated/drained substrate), obtained at maximum intervals of 15 days, with averages of $0.1535 \mathrm{~cm}^{3} \mathrm{~cm}^{-3}$ of substrate and maximum variation of $5.2 \%$ over the experimental period.

The factorial scheme adopted was 5 x 4 (shading screens $\mathrm{x}$ water replacement levels), on completely randomized design in the interior of shading modules, with three replicates (15 nurseries - experimental units). In each nursery, four replications ( 54 seedlings each) were evaluated for the different levels of water replacement.

The seedlings were cultivated on nursery benches, arranged in the east-west direction, with dimensions of $3.0 \times 1.0 \times 1.0 \mathrm{~m}$ (length, width and height). These experimental modules were covered on top, front and sides with black agricultural polyester nets with $35,50,65$ and $80 \%$ of shading, in addition to the full sun condition. In-loco evaluations were performed between 10 and $14 \mathrm{~h}$, to characterize the instantaneous attenuations of global radiation $\left(\mathrm{I}_{\mathrm{G}}\right)$, photosynthetically active radiation $\left(\mathrm{I}_{\mathrm{PAR}}\right)$ and luminance (Table 1).

During the experiment, in the condition of full sun, the meteorological variables were measured with an automatic station with the following sensors: PAR radiation (Licor) at $2 \mathrm{~m}$ height, wind speed and direction (anemometer, 03002-L RM Young) at $10 \mathrm{~m}$ height, psychrometer with thermometric shelter (Vaisala, CS 215) at $2 \mathrm{~m}$ height, rain gauge (TE 525) at $1.5 \mathrm{~m}$ height and sunshine recorder. Data acquisition was performed using a CR1000 datalogger operating at 1-Hz frequency and storing averages of 300 readings or $5 \mathrm{~min}$. Inside the nurseries, for routine measurements (30-min intervals) of temperature and relative humidity, thermohygrometers (KlimaLogg Pro, TFA Dostmann GmbH \& Co.KG) were installed at $1.50 \mathrm{~m}$ height, centralized inside each experimental nursery.

Destructive growth analyses were carried out at 20,52 and 87 days after transplanting (DAT), determining seedling height (measured from the collar to the apical bud), stem diameter (measured at the seedling collar), number of leaves

Table 1. Percentages of average transmissivity of global radiation $\left(\mathrm{I}_{\mathrm{G}}\right)$, photosynthetically active radiation $\left(\mathrm{I}_{\mathrm{PAR}}\right)$ and luminance for different types of black polyester nets, in Sinop, MT state, Brazil

\begin{tabular}{cccc}
\hline $\begin{array}{c}\text { Commercial } \\
\text { nets }\end{array}$ & \multicolumn{1}{c}{$\mathrm{I}_{\mathrm{G}}$} & \multicolumn{1}{c|}{ Luminance } & \multicolumn{1}{c|}{ IPAR } \\
\hline Black 35\% & $54.72 \pm 8.62^{\mathrm{a}}$ & $51.67 \pm 6.39$ & $53.25 \pm 6.42$ \\
Black 50\% & $35.59 \pm 13.69$ & $35.08 \pm 12.39$ & $33.55 \pm 13.24$ \\
\hline Black 65\% & $25.25 \pm 10.50$ & $23.91 \pm 10.69$ & $23.29 \pm 11.26$ \\
\hline Black 80\% & $13.77 \pm 8.34$ & $12.30 \pm 7.99$ & $12.58 \pm 9.58$ \\
\hline
\end{tabular}

${ }^{\mathrm{a}}$ Mean \pm standard deviation 
(considering only fully expanded leaves), root dry mass (RDM) and shoot dry mass (SDM - stem + leaves) and total leaf area of the seedlings (determined with Li-3100 area meter).

The daily evapotranspiration of the seedlings (ETc) was obtained by the direct weighing of four trays with 54 tubes (four replicates) for each shading condition. The daily ETc was adopted as a reference for the water replacement (100\%), applied manually (volume of water individualized per tube, split so as to not exceed the WRC $-44.5 \mathrm{~cm}^{3}$ tube $\mathrm{e}^{-1}$ ). The other values of water replacement evaluated were 75,50 and $25 \%$ of ETc, also applied manually.

After obtaining the ETc, the crop coefficients (kc) were defined by the ratio between ETc and reference evapotranspiration $\left(\mathrm{ET}_{0}\right)$ obtained by the Penman-Monteith FAO-56 method (Allen et al., 1998; Monteiro et al., 2016). The coefficient of response of the seedlings to water deficit (ky) was obtained according to Eq. 1, and in this case the potential yield $\left(\mathrm{Y}_{\mathrm{m}}\right)$ in total dry mass of the seedling and the potential evapotranspiration $\left(\mathrm{ET}_{\mathrm{m}}\right)$ were obtained at the level of $100 \%$ water replacement, for each shading condition.

$$
1-\frac{\mathrm{Y}_{\mathrm{r}}}{\mathrm{Y}_{\mathrm{m}}}=\mathrm{ky}\left(1-\frac{\mathrm{ET}_{\mathrm{r}}}{\mathrm{ET}_{\mathrm{m}}}\right)
$$

where:

$\mathrm{Y}_{\mathrm{r}}$ and $\mathrm{Y}_{\mathrm{m}}$ - actual and potential maximum yield, respectively, $\mathrm{kg} \mathrm{ha}{ }^{-1}$; and,

$\mathrm{ET}_{\mathrm{r}}$ and $\mathrm{ET}_{\mathrm{m}}$ - actual and maximum evapotranspiration, respectively, $\mathrm{mm}$.

The accumulated degree-days (ADD) were determined using the methodology of Ometto recommended by Souza et al. (2011), considering minimum (Tb) and maximum (TB) basal temperatures of 14.5 and $34.4{ }^{\circ} \mathrm{C}$, respectively.

The data were subjected to analysis of variance by $\mathrm{F}$ test and, when significant, means were compared by Tukey test at $\mathrm{p} \leq 0.05$, or regressions were adjusted for the quantitative variables.

A.

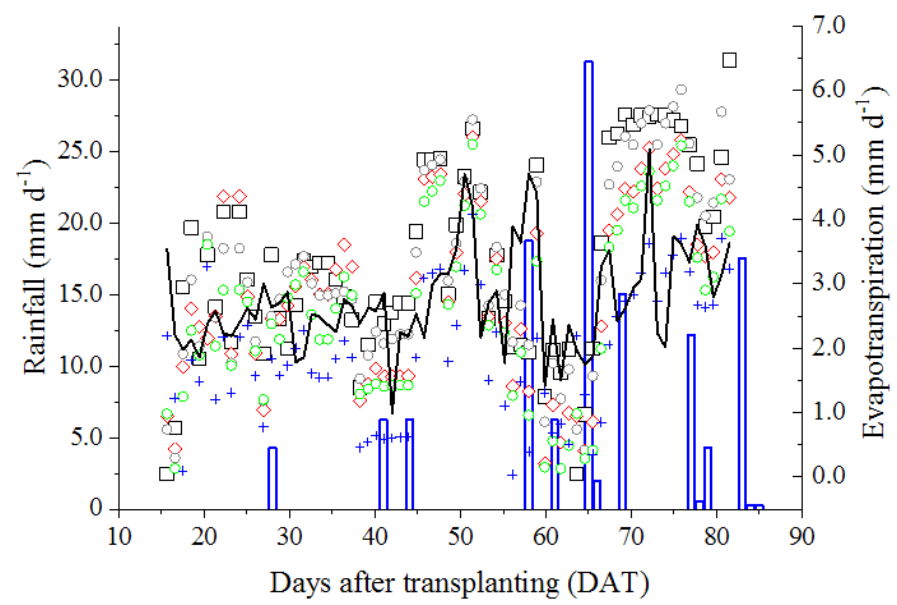

\section{Results AND Discussion}

The reference evapotranspiration $\left(\mathrm{ET}_{0}\right)$ showed large oscillations after $30 \mathrm{DAT}$, with minimum of $0.42 \mathrm{~mm} \mathrm{~d}^{-1}$ and maximum of $5.09 \mathrm{~mm} \mathrm{~d}^{-1}$ (Figure 1A), whereas until 27 DAT the mean value of $\mathrm{ET}_{0}$ was $2.46 \mathrm{~mm} \mathrm{~d}^{-1}$. These oscillations of $\mathrm{ET}_{0}$ occurred in response to variations in the water vapor deficit in the atmosphere and its relations with the incidence of solar radiation and soil water availability to plants (Lemos Filho et al., 2010; Coletti et al., 2012; Pereira et al., 2013).

The daily variations of the evapotranspiration of Amazonian yellow ipe seedlings (ETc), regardless of the level of shading, showed similar behavior to that of $\mathrm{ET}_{0}$ (Figure 1A), with reductions in the periods of greater cloudiness and rainfalls.

The average ETc in the shading levels was equal to 3.37, $3.22,2.87,2.61$ and $1.92 \mathrm{~mm} \mathrm{~d}^{-1}$ for full sun and black polyester nets with $35,50,65$ and $80 \%$ shading, respectively. In this case, $80 \%$ shading led to lower values of ETc, with range of variation from 0.03 to $4.07 \mathrm{~mm} \mathrm{~d}^{-1}$, whereas under full sun, the maximum ETc reached $6.47 \mathrm{~mm} \mathrm{~d}^{-1}$. The values of ETc obtained in this study corroborate those reported by Fausto et al. (2017), who found average ETc of $3.17 \mathrm{~mm} \mathrm{~d}^{-1}$ for cashew seedlings, using constant-level water-table lysimeters.

The variation of the ETc of Amazonian yellow ipe throughout the experimental period can be attributed to the meteorological conditions and development of the seedlings. However, it is worth pointing out that, when the crop does not have a remarkable differentiation of phenological stage, the variation in water requirement results mainly from the evaporation of water from the soil (substrate) and irrigation management conditions (Allen et al., 1998; Monteiro et al., 2016).

The accumulated depths of $\mathrm{ET}_{0}$ (Figure $1 \mathrm{~B}$ ) and rainfall (Figure 1A) at 86 DAT were 195.2 and $90.0 \mathrm{~mm}$, respectively, whereas the accumulated ETc was equal to 239.2, 228.6, 204.1, 185.7 and $136.3 \mathrm{~mm}$ for the cultivation under full sun and 35, 50, 65 and 80\% shading, respectively (Figure 1B). These differences in ETc represent a $43 \%$ reduction in the

$$
\text { B. }
$$

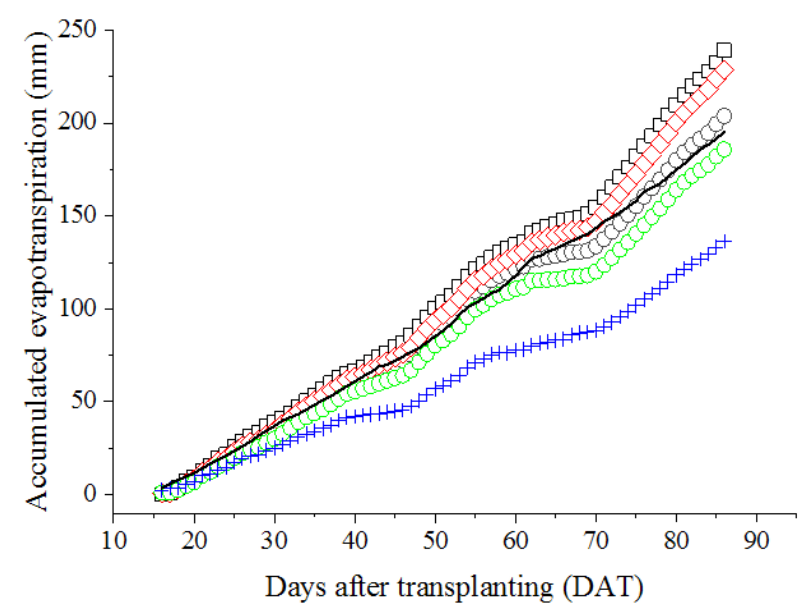

Rainfall $\square 0 \%$ - FS (Full sun) $\quad 35 \% \diamond 50 \% \quad 65 \%+80 \%-$ ETo

Figure 1. Rainfall, reference evapotranspiration $\left(\mathrm{ET}_{0}\right)$ and crop evapotranspiration (A) and accumulated potential evapotranspiration (B) of Amazonian yellow ipe seedlings under different shading conditions, in Sinop, MT, Brazil, between July 20 and October 14, 2016 
accumulated water demand of the yellow ipe seedlings under $80 \%$ shading when compared with seedlings under full sun. The intensity of the solar radiation incident on the plants is proportionally related to the variation of the evapotranspiration of a vegetated surface (Lozano et al., 2017), since the increase of global radiation, depending on the radiation balance, can be accompanied by higher availability of latent heat and sensible heat, consequently increasing the ETc.

Therefore, the increase in the shading level reduced the crop coefficients $(\mathrm{kc})$, regardless of the development stage of the seedlings (Figure 2). The fitted regressions (second-order polynomials) for estimates of kc at the different levels showed the accumulated thermal sum as independent variable and had determination coefficients $\left(R^{2}\right)$ between 0.72 and 0.83 , that can

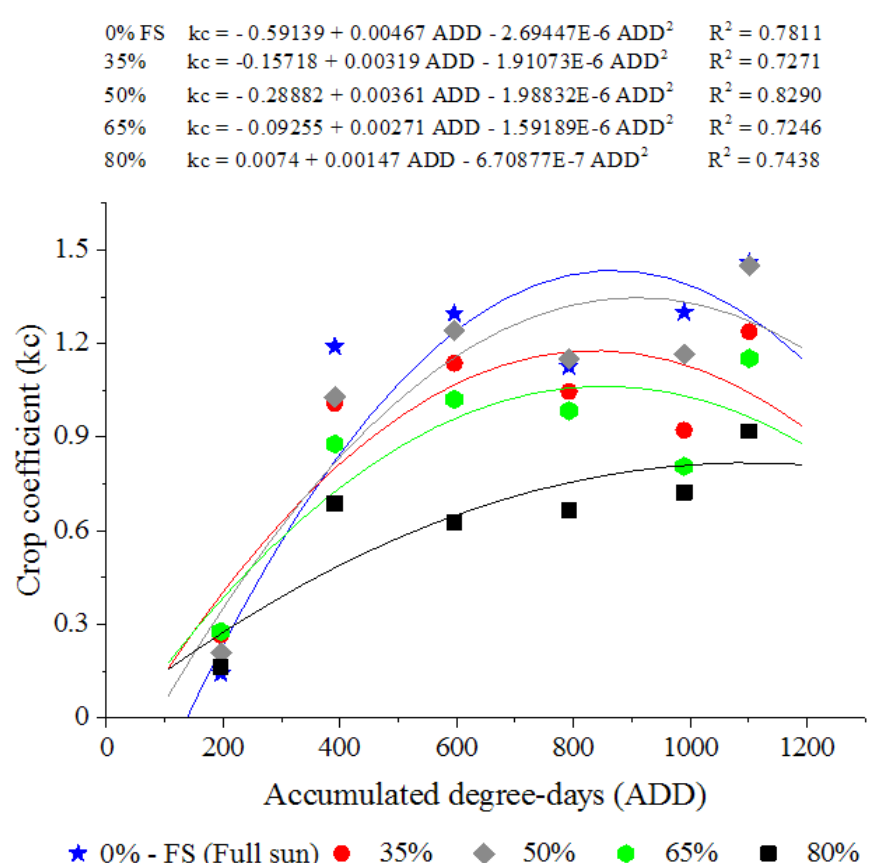

Figure 2. Crop coefficients (kc) of Amazonian yellow ipe seedlings under different shading conditions as a function of the accumulated degree-days be considered satisfactory, since the crop used in this study is a tree species and, therefore, does not exhibit remarkable differentiation of phenological stages in the seedling phase.

The initial accumulated thermal sum for the different shading levels was $391.49 \mathrm{ADD}$, and the $\mathrm{kc}$ values for this period were $0.823,0.798,0.820,0.724$ and 0.465 under the conditions of full sun and shading of 35, 50, 65 and 80\%, respectively. In the intermediate phase, the accumulated thermal sum was $792.5 \mathrm{ADD}$, with mean kc values of 1.417 , $1.171,1.323,1.055$ and 0.736 . At the end of the experiment (87 DAT), the accumulated thermal sum was $1101.6 \mathrm{ADD}$ and the mean kc values were $1.283,1.038,1.275,0.961$ and 0.798 for the same cultivation conditions cited above.

With regard to forest species, studies on applications of thermal sum are scarce, especially associating kc patterns with accumulated degree-days, thus corroborating the relevance of these applications for irrigation managements based on meteorological variables that can be monitored at a low cost.

As for the morphometric growth variables of the seedlings, it was observed that their height was influenced by both shading levels and water replacement levels, regardless of the period of the cycle (Table 2); however, no pattern of effect of increment and/or reduction was observed.

At 52 DAT, the first occurrences of seedling death were observed in the replacement of 25\% ETc under shading levels of 35 and $50 \%$. This fact demonstrates a considerable tolerance of Amazonian yellow ipe seedlings to water stress; however, under water replacements lower than $75 \%$ ETc, in general, the plant does not complete the seedling phase (exception for the $35 \%$ shade net). Thus, the irrigation management conditions in nurseries for this species should consider the replacements of 75 and $100 \%$ ETc, which lead to better plant development.

The effects of irrigation depths on the height and diameter of seedlings of forest or fruit species vary depending on plant size, growth habit, type of leaf, characteristics of the substrate and the growing container, in addition to the microclimatic conditions of the growing environment (Monteiro et al., 2016).

Table 2. Morphometric variables of Amazonian yellow ipe seedlings in different periods of evaluation, water replacement (WR) levels and shading levels (SL)

\begin{tabular}{|c|c|c|c|c|c|c|c|c|c|c|c|c|}
\hline \multirow{2}{*}{$\begin{array}{l}\text { WR } \\
(\%)\end{array}$} & \multicolumn{4}{|c|}{$09 / 08 / 2016$ - 20 DAT } & \multicolumn{4}{|c|}{ 09/09/2016 - 52 DAT } & \multicolumn{4}{|c|}{ 15/10/2016 - 87 DAT } \\
\hline & 25 & 50 & 75 & 100 & 25 & 50 & 75 & 100 & 25 & 50 & 75 & 100 \\
\hline \multicolumn{13}{|c|}{ Plant height $(\mathrm{cm})$} \\
\hline $0 \%(\mathrm{FS})$ & $4.00 \mathrm{ABa}$ & $4.14 \mathrm{Ba}$ & $3.77 \mathrm{Ba}$ & $4.04 \mathrm{Ca}$ & $6.43 \mathrm{Ba}$ & $4.14 \mathrm{Cb}$ & 5.60 Bab & $5.16 \mathrm{Cab}$ & - & - & $7.01 \mathrm{Ba}$ & $8.22 \mathrm{Ba}$ \\
\hline $35 \%$ & $3.99 \mathrm{ABb}$ & $3.94 \mathrm{Bb}$ & $5.33 \mathrm{ABa}$ & $5.41 \mathrm{Ba}$ & - & $5.10 \mathrm{BCb}$ & 6.72 Bab & $7.83 \mathrm{Ba}$ & - & 6.38 & $8.21 \mathrm{ABa}$ & $9.86 \mathrm{ABa}$ \\
\hline $50 \%$ & 4.52 Aab & $5.11 \mathrm{Aa}$ & 4.24 Bab & $3.88 \mathrm{Cb}$ & - & $5.73 \mathrm{Bb}$ & 6.58 Bab & $7.13 \mathrm{Ba}$ & - & - & $6.67 \mathrm{Ba}$ & $7.48 \mathrm{Ba}$ \\
\hline $65 \%$ & $3.23 \mathrm{Bc}$ & $3.82 \mathrm{Bbc}$ & $6.17 \mathrm{Aa}$ & $4.54 \mathrm{Cb}$ & $5.42 \mathrm{Bb}$ & 6.33 Bab & $8.35 \mathrm{Aa}$ & $8.04 \mathrm{Aa}$ & - & - & $10.09 \mathrm{Aa}$ & $11.14 \mathrm{Aa}$ \\
\hline $80 \%$ & $4.96 \mathrm{Ac}$ & $5.83 \mathrm{Ab}$ & $4.97 \mathrm{ABc}$ & $7.06 \mathrm{Aa}$ & $8.10 \mathrm{Aa}$ & $8.23 \mathrm{Aa}$ & $6.48 \mathrm{Bb}$ & $9.48 \mathrm{Aa}$ & - & - & $7.58 \mathrm{ABb}$ & $11.68 \mathrm{Aa}$ \\
\hline \multicolumn{13}{|c|}{ Stem diameter $(\mathrm{mm})^{1}$} \\
\hline $0 \%(\mathrm{FS})$ & 1.0 & 1.2 & 1.2 & 1.2 & 1.4 & 1.6 & 1.6 & 1.8 & - & - & 2.6 & 1.8 \\
\hline $35 \%$ & 0.7 & 0.8 & 1.0 & 0.9 & - & 1.1 & 1.6 & 1.9 & - & 1.9 & 2.0 & 2.3 \\
\hline $50 \%$ & 0.7 & 0.9 & 0.7 & 0.8 & - & 1.5 & 1.8 & 2.2 & - & - & 1.8 & 2.4 \\
\hline $65 \%$ & 0.6 & 0.9 & 1.1 & 0.9 & 1.3 & 1.6 & 2.3 & 1.8 & - & - & 2.3 & 2.6 \\
\hline $80 \%$ & 0.8 & 1.1 & 1.0 & 1.0 & 1.9 & 2.4 & 1.6 & 2.0 & - & - & 1.3 & 2.2 \\
\hline \multicolumn{13}{|c|}{ Number of leaves } \\
\hline $0 \%(\mathrm{FS})$ & $3.9 \mathrm{Ba}$ & 3.6 Ba & $4.0 \mathrm{Ca}$ & $4.5 \mathrm{Ca}$ & $4.7 \mathrm{Ba}$ & $3.6 \mathrm{Bb}$ & 4.6 Cab & $4.9 \mathrm{Ca}$ & - & - & 4.4 Aa & $5.7 \mathrm{Ca}$ \\
\hline $35 \%$ & $5.1 \mathrm{Aa}$ & $5.5 \mathrm{Aa}$ & $5.2 \mathrm{Ba}$ & $5.2 \mathrm{Ba}$ & - & $3.7 \mathrm{Bb}$ & $4.7 \mathrm{Cb}$ & $6.3 \mathrm{Ba}$ & - & 5.4 & 4.6 Ab & $11.4 \mathrm{Aa}$ \\
\hline $50 \%$ & $4.8 \mathrm{ABb}$ & $5.9 \mathrm{Aa}$ & 5.1 Bab & $4.8 \mathrm{Bb}$ & - & $4.3 \mathrm{Bb}$ & $5.4 \mathrm{BCb}$ & $7.7 \mathrm{Aa}$ & - & - & $5.9 \mathrm{Ab}$ & $8.0 \mathrm{Ba}$ \\
\hline $65 \%$ & $4.2 \mathrm{Bb}$ & $4.2 \mathrm{Bb}$ & $6.5 \mathrm{Aa}$ & $5.7 \mathrm{ABa}$ & $5.8 \mathrm{Bb}$ & $5.7 \mathrm{Ab}$ & $8.6 \mathrm{Aa}$ & $7.6 \mathrm{Aa}$ & - & - & 4.7 Ab & $7.6 \mathrm{Ba}$ \\
\hline $80 \%$ & $5.6 \mathrm{Aab}$ & $5.2 \mathrm{Ab}$ & 5.8 ABab & $6.3 \mathrm{Aa}$ & $7.0 \mathrm{Ab}$ & $5.7 \mathrm{Ac}$ & $6.3 \mathrm{Bbc}$ & $8.3 \mathrm{Aa}$ & - & - & $4.3 \mathrm{Ab}$ & 7.7 $\mathrm{Ba}$ \\
\hline
\end{tabular}

Means followed by the same uppercase and lowercase letters, in the column and in the row, respectively (for the same morphometric variable and period of collection), do not differ by Tukey test at $\mathrm{p} \leq 0.05$; FS - Full sun; ${ }^{1}$ - No significant differences were observed for stem diameter 
In general, water deficit caused by smaller irrigation depths tends to restrict the growth of forest seedlings in diameter and height (Cabral et al., 2004; Lenhard et al., 2010; Scalon et al., 2011; Ferreira et al., 2015; Silva et al., 2015a, b; Duarte et al., 2016). However, in this experiment no significant differences were observed for the increment in stem diameter, regardless of the cultivation condition.

The number of leaves under the condition of potential evapotranspiration (100\% water replacement) was lower in the cultivation under full sun, regardless of age (Table 2). At 87 DAT, the water deficits caused by the replacement of $75 \%$ ETc reduced the number of leaves in $22.8 \%$ (full sun) and in $59.6 \%$ (35\% shading), when compared to the replacement of $100 \%$ ETc. These percentages of leaf abscission depend on the resistance of the species to water deficit and agree with results reported by Duarte et al. (2016), who obtained a $40 \%$ reduction in the number of leaves of 'paricá' seedlings subjected to a $50 \%$ reduction in the volume applied in the reference cultivation.

Greater proportion of leaf number and height was also observed by Cabral et al. (2004), in Tabebuia aurea seedlings grown with replacement of $100 \%$ field capacity (FC). However, the lower water supply (25\% FC) caused a lower increment in the aforementioned variables, the authors state that this species is tolerant to water stress.

A.

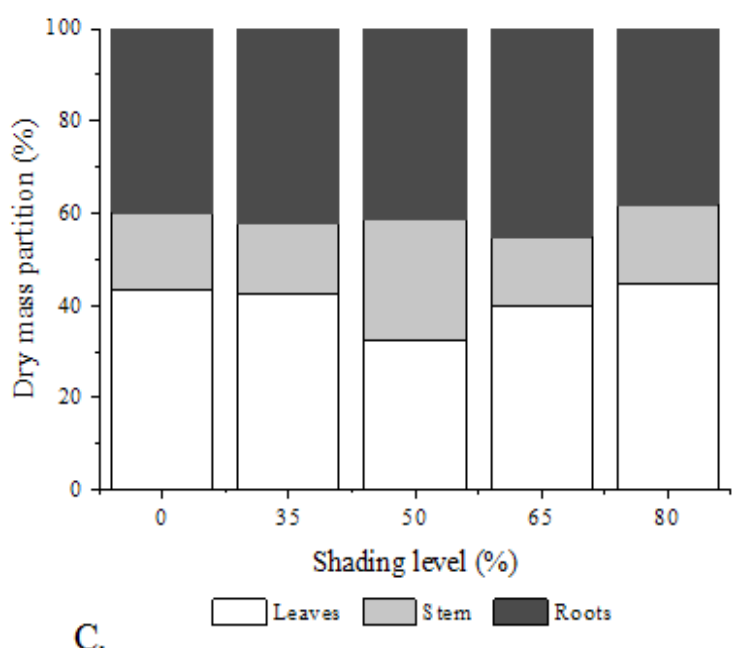

C.

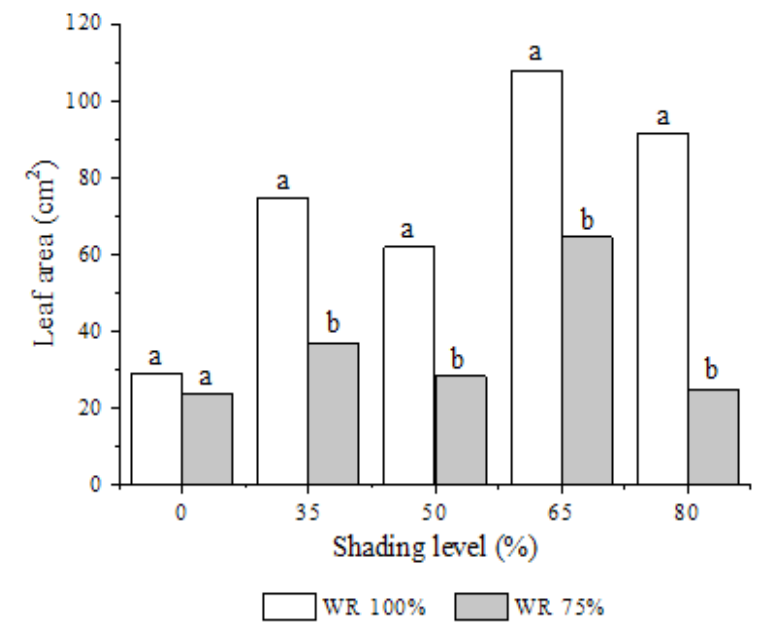

For tropical plants, with fast growth, the water supply tends to affect growth and development more than all environmental factors combined (Lenhard et al., 2010; Scalon et al., 2011; Ferreira et al., 2015). Thus, the shading associated with the different levels of water replacement can promote more pronounced and direct effects on evapotranspiration through temperature variations than on the growth variables (Monteiro et al., 2016). Oliveira \& Perez (2012) state that water can limit plant growth in environments with higher intensity of solar radiation, whereas light can become a limiting factor to plant growth in shaded environments.

The analyses of dry mass partitions and leaf area were carried out in the treatments of 75 and $100 \%$ water replacement (Figures 3A and B), because these were the only levels of water replacement in which there were surviving plants at the end of the experiment.

Regardless of the level of water replacement (100 and 75\% ETc), the pattern of partition of leaf, stem and root dry masses was similar under all shading levels and no significant differences were observed. This may demonstrate a capacity of adaptation of Amazonian yellow ipe seedlings to different luminosity levels, provided they are not cultivated under water stress conditions.

According to Lorenzi (1992), the Amazonian yellow ipe is a heliophyte, classified in the successional group of late

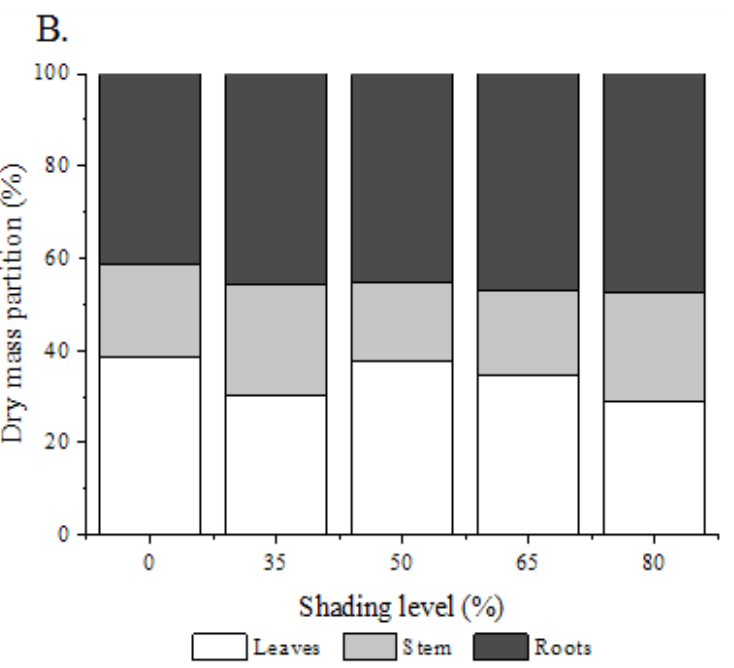

D.

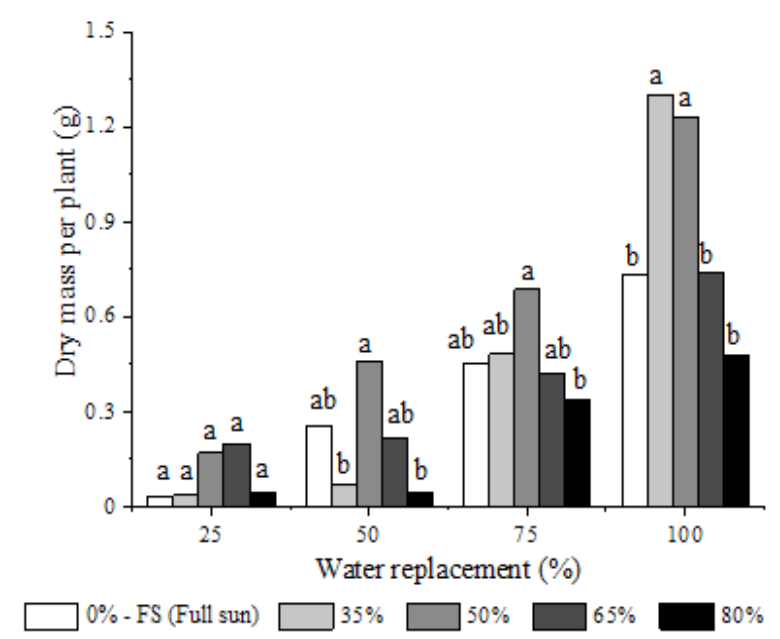

Means followed by the same letters at same level do not differ by Tukey test at $\mathrm{p} \leq 0.05$

Figure 3. Dry mass partitions at 100\% water replacement (A) and 75\% water replacement (B), leaf area (C) and dry mass (D) of Amazonian yellow ipe seedlings at different levels of shading and water replacement (WR), at 87 DAT 
secondary, so it can grow satisfactorily in environments with high luminosity. However, according to Aguiar et al. (2011), intermediate species, as is the case of Amazonian yellow ipe, can respond, in terms of growth, both to the condition of intense radiation and to certain levels of shading.

Leaf area was significantly higher in plants under $100 \%$ water replacement (Figure 3C). 65\% shading led to the largest leaf areas under 100 and $75 \%$ water replacements, with 107.97 and $64.54 \mathrm{~cm}^{2}$, respectively. These results corroborate several studies with seedlings of various tree species, cultivated under different shading levels, which indicate a progressive quadratic increment of leaf area as a function of increased shading (Cabral et al., 2004; Mota et al., 2012; Oliveira \& Perez, 2012; Nery et al., 2016).

Change of leaf area in response to an environmental factor constitutes a mechanism developed by plants to compensate for the lower intensities of incident solar radiation (Larcher, 2004). Therefore, such behavior may be an additional indication that the Amazonian yellow ipe is a species that has adaptation to different luminosity conditions.

The dry mass of the plant increased with the increment in the water replacement levels (Figure 3D). The application of $100 \%$ ETc led to increments of $69.7,126.9,105.9,54.3$ and $43.4 \%$ in the dry mass yields, compared to the replacement of $25 \%$ ETc, under the conditions of full sun and 35, 50, 65 and $80 \%$ shading, respectively.

In this context, based on the joint analysis of the morphometric parameters, it can be indicated that the optimum irrigation depth for this species is given by the replacement of $100 \%$ ETc, with cultivation under black net with $35 \%$ shading, a condition that led to highest biomass accumulation (1.3035 $\left.\mathrm{g} \mathrm{plant}^{-1}\right)$. These results also show that, in this case, the limiting factor for plant biomass production is water and not the intensity of incident radiation.

Similar results have been found by Mota et al. (2012) for seedlings of Dipteryx alata, by Ferreira et al. (2012) for seedlings of Piptadenia stipulacea and Anadenanthera colubrina, and by Nery et al. (2016) for seedlings of Calophyllum brasiliense. In these cases, the highest increments of dry mass were also observed under intermediate shading levels.

Table 3 shows the mean values of the parameters that compose the analysis of the water sensitivity coefficients (ky), considering the dry mass yields according to the volume of water applied. In this case, the $100 \%$ water replacement was considered as a reference for the potential biomass yield.

According to Doorenbos \& Kassam (1979), the higher the value of ky under deficit irrigation conditions, the crop will have higher yield losses as a response to water deficit. Therefore, ky values lower than 1 indicate that the crop can be tolerant to water deficit under the conditions to which it is exposed, or, at the phenological stage in which it is, and in this situation, the reduction of dry mass yield is lower than the water restriction to which the plant was subjected. By contrast, values greater than 1 may indicate that the plant is sensitive to deficit irrigation, and the reduction of yield is larger (Silva et al., 2014).

There is a decrease in ky values with the increase in the water replacement level, with variations from 0.89 to $1.04 ; 1.06$ to 1.18 and 1.10 to 1.28 for water replacements of 75,50 and $25 \%$, respectively. Thus, it can be verified that the reduction in the relative dry mass yield $(1-\mathrm{Yr} / \mathrm{Ym})$ of the plants was more pronounced under the $25 \%$ water replacement, regardless of the level of shading.

Among the different shading levels, water restriction had a higher impact on dry mass yield under $80 \%$ shading and $25 \%$ water replacement $(\mathrm{ky}=1.28)$. However, for causing an accentuated reduction of accumulated ETc, this same shading level also led to the smallest effect of water deficit on the dry mass production of the plants with the increase in the level of water replacement $(\mathrm{ky}=0.89)$.

Sensitivity to water deficit can be classified into four categories according to Doorenbos \& Kassam (1979): ky $<0.85$ low, $0.85<\mathrm{ky}<1.00$ - low/medium, $1.00<\mathrm{ky}<1.15$ - medium/ high and ky $>1.15$ - high. Therefore, the obtained results show that Amazonian yellow ipe seedlings have higher water sensitivity under conditions of deficit irrigation associated with higher levels of shading.

Studies on the water sensitivity factor for tree crops are scarce, so there are no reference values of ky for comparative analysis, unlike what occurs for agricultural crops.

The short range of variation of ky in the present study can be explained by the fact that forest species in the seedling phase exhibit only one phenological stage, the vegetative

Table 3. Water sensitivity of Amazonian yellow ipe seedlings under different shading conditions and water replacement levels

\begin{tabular}{|c|c|c|c|c|c|c|c|c|}
\hline \multirow{2}{*}{ Shading level } & \multirow{2}{*}{$\begin{array}{c}\text { Water } \\
\text { replacement }\end{array}$} & $\mathrm{ETr}^{1}$ & $\mathrm{ETm}^{2}$ & \multirow{2}{*}{ (1-ETr/ETm) } & $\mathrm{Yr}^{3}$ & $Y \mathrm{~m}^{4}$ & \multirow{2}{*}{ (1-Yr/Ym) } & \multirow{2}{*}{ ky } \\
\hline & & \multicolumn{2}{|c|}{$(\mathrm{mm})$} & & \multicolumn{2}{|c|}{$\left(g^{-2}\right)$} & & \\
\hline \multirow{3}{*}{$0 \%(\mathrm{FS})$} & $25 \%$ & 55.99 & 239.18 & 0.77 & 31.68 & 340.46 & 0.91 & 1.18 \\
\hline & $50 \%$ & 37.39 & 239.18 & 0.84 & 31.68 & 340.46 & 0.91 & 1.07 \\
\hline & $75 \%$ & 166.22 & 239.18 & 0.31 & 239.41 & 340.46 & 0.30 & 0.97 \\
\hline \multirow{3}{*}{$35 \%$} & $25 \%$ & 27.64 & 203.77 & 0.86 & 23.57 & 519.93 & 0.95 & 1.10 \\
\hline & $50 \%$ & 78.71 & 203.77 & 0.61 & 180.86 & 519.93 & 0.65 & 1.06 \\
\hline & $75 \%$ & 129.87 & 203.77 & 0.36 & 323.11 & 519.93 & 0.38 & 1.04 \\
\hline \multirow{3}{*}{$50 \%$} & $25 \%$ & 39.83 & 228.58 & 0.83 & 24.71 & 928.10 & 0.97 & 1.18 \\
\hline & $50 \%$ & 36.89 & 228.58 & 0.84 & 47.49 & 928.10 & 0.95 & 1.13 \\
\hline & $75 \%$ & 90.55 & 228.58 & 0.60 & 344.18 & 928.10 & 0.63 & 1.04 \\
\hline \multirow{3}{*}{$65 \%$} & $25 \%$ & 53.66 & 185.73 & 0.71 & 121.11 & 874.98 & 0.86 & 1.21 \\
\hline & $50 \%$ & 87.61 & 185.73 & 0.53 & 327.59 & 874.98 & 0.63 & 1.18 \\
\hline & $75 \%$ & 101.13 & 185.73 & 0.46 & 487.79 & 874.98 & 0.44 & 0.97 \\
\hline \multirow{3}{*}{$80 \%$} & $25 \%$ & 58.52 & 136.28 & 0.57 & 140.90 & 527.33 & 0.73 & 1.28 \\
\hline & $50 \%$ & 52.08 & 136.28 & 0.62 & 155.14 & 527.33 & 0.71 & 1.14 \\
\hline & $75 \%$ & 69.68 & 136.28 & 0.49 & 298.11 & 527.33 & 0.43 & 0.89 \\
\hline
\end{tabular}

${ }^{1}$ ETr - Accumulated real evapotranspiration; ${ }^{2}$ ETm - Accumulated maximum evapotranspiration in the treatment with $100 \%$ replacement, representing the ETc; ${ }^{3}$ Yr - Real yield;

${ }^{4} \mathrm{Ym}$ - Maximum yield in the treatment with $100 \%$ replacement; ky - Water sensitivity coefficient (dimensionless); FS - Full sun 
stage. According to Doorenbos \& Kassam (1979), the greatest contributions to the variations of ky values come from changes in phenological stages of the plant and its interactions with environmental conditions, especially in the reproductive stages.

\section{Conclusions}

1. The daily water consumption of Amazonian yellow ipe seedlings decreases with the increase in the shading level.

2. Amazonian yellow ipe is sensitive to water deficit in the seedling phase, with greater limitations of yield (dry mass) under conditions of full sun and increased shading level.

3. For the production of Amazonian yellow ipe seedlings, it is recommended the irrigation depth of $100 \%$ ETc, under $35-50 \%$ shading, for regions with meteorological seasonality similar to that of the studied area.

\section{Literature Cited}

Aguiar, F. F. A.; Kanashiro, S.; Tavares, A. R.; Nascimento, T. D. R. do; Rocco, F. M. Crescimento de mudas de pau-brasil (Caesalpinia echinata Lam.), submetidas a cinco níveis de sombreamento. Revista Ceres, v.58, p.729-734, 2011. https://doi.org/10.1590/ S0034-737X2011000600008

Allen, R. G.; Pereira, L. S.; Raes, D.; Smith, M. Crop evapotranspiration: Guidelines for computing crop water requirements. Rome: FAO, 1998. 300p.

Cabral, E. L.; Barbosa, D. C. de A.; Simabukuro, E. A. Crescimento de plantas jovens de Tabebuia aurea (Manso) Benth. \& Hook. f. ex S. Moore submetidas a estresse hídrico. Acta Botanica Brasilica, v.18, p.241-251, 2004. https://doi.org/10.1590/S010233062004000200004

Coletti, A. J.; Dallacort, R.; Dalchiavon, F. C.; Martins, J. A.; Santi, A.; Inoue, M. H. Evapotranspiração e coeficiente de cultivo da cultura do pinhão manso. Revista Agrarian, v.5, p.373-383, 2012.

Doorenbos, J.; Kassam, A. H. Yield response to water. Rome: FAO, 1979. Technical Note, 33. https://doi.org/10.1016/B978-0-08025675-7.50021-2

Duarte, D. M.; Rocha, G. T.; Lima, F. B. de; Matos, F. S.; Rodrigues, F. Responses of paricá seedlings to water stress. Floresta, v.46, p.405-412, 2016. https://doi.org/10.5380/rf.v46i3.39529

Fausto, M. A.; Rihbane, F. E. C.; Campelo Júnior, J. H.; Lobo, F. de A.; Ortíz, C. E. R. Coeficiente de cultura e necessidades hídricas de mudas de cajueiro anão em condições de cerrado. Ambiência, v.13, p.301-310, 2017. https://doi.org/10.5935/ambiencia.2017.02.03

Fávero, C.; Lovo, I. C.; Mendonça, E. de S. Recuperação de área degradada com sistema agroflorestal no Vale do Rio Doce, Minas Gerais. Revista Árvore, v.32, p.861-868, 2008. https://doi. org/10.1590/S0100-67622008000500011

Ferreira, L.; Chalub, D.; Muxfeldt, R. Ipê-amarelo: Tabebuia serratifolia (Vahl) Nichols. Manaus: INPA, 2004. 2p. Informativo Técnico Rede de Sementes da Amazônia, 5

Ferreira, W. N.; Lacerda, C. F. de; Costa, R. C. da; Medeiros Filho, S. Effect of water stress on seedling growth in two species with different abundances: The importance of stress resistance syndrome in seasonally dry tropical forest. Acta Botanica Brasilica, v.29, p.375-382, 2015. https://doi.org/10.1590/010233062014 abb0045
Ferreira, W. N.; Zandavalli, R. B.; Bezerra, A. M. E.; Medeiros Filho, S. Crescimento inicial de Piptadenia stipulacea (Benth.) Ducke (Mimosaceae) e Anadenanthera colubrina (Vell.) Brenan var. cebil (Griseb.) Altshul (Mimosaceae) sob diferentes níveis de sombreamento. Acta Botanica Brasilica, v.26, p.408-414, 2012. https://doi.org/10.1590/S0102-33062012000200016

Grose, S. O.; Olmstead, R. G. Taxonomic revisions in the polyphyletic genus Tabebuia s. 1. (Bignoniaceae). Systematic Botany, v.32, p.660-670, 2007. https://doi.org/10.1600/036364407782250652

Larcher, W. Ecofisiologia vegetal. São Carlo: Rima, 2004. 531p.

Lemos Filho, L. C. A.; Carvalho, L. G.; Evangelista, A. W. P.; Alves Junior, J. Análise espacial da influência dos elementos meteorológicos sobre a evapotranspiração de referência em Minas Gerais. Revista Brasileira de Engenharia Agrícola e Ambiental, v.14, p.1294-1303, 2010. https://doi.org/10.1590/ S1415-43662010001200007

Lenhard, N. R.; Scalon, S. de P. Q.; Novelino, J. O. Crescimento inicial de mudas de pau ferro (Caesalpinia ferrea Mart. ex Tul. var. leiostachya Benth.) sob diferentes regimes hídricos. Ciência e Agrotecnologia, v.34, p.870-877, 2010. https://doi. org/10.1590/S1413-70542010000400011

Lorenzi, H. Árvores brasileiras: Manual de identificação e cultivo de plantas arbóreas nativas do Brasil. 1.ed. Nova Odessa: Instituto Plantarum, 1992. 352p.

Lozano, C. S.; Rezende, R.; Freitas, P. S. L. de; Hachmann, T. L.; Santos, F. A. S.; Andrean, A. F. B. A. Estimation of evapotranspiration and crop coefficient of melon cultivated in protected environment. Revista Brasileira de Engenharia Agrícola e Ambiental, v.21, p.758-762, 2017. https://doi. org/10.1590/1807-1929/agriambi.v21n11p758-762

Monteiro, E. B.; Silva, A. C. da; Souza, A. P.; Tanaka, A. A.; Ferneda, B. G.; Martim, C. C. Water requirements and crop coefficients of tropical forest seedlings in different shading conditions. Revista Brasileira de Engenharia Agrícola e Ambiental, v.20, p.709-715, 2016. https://doi.org/10.1590/1807-1929/agriambi. v20n8p709-715

Mota, L. H. de S.; Scalon, S. de P. Q.; Heinz, R. Sombreamento na emergência de plântulas e no crescimento inicial de Dipteryx alata Vog. Ciência Florestal, v.22, p.423-432, 2012. https://doi. org/10.5902/198050986611

Nery, F. C.; Prudente, D. de O.; Alvarenga, A. A. de; Paiva, R.; Nery, M. C. Desenvolvimento de mudas de guanandi (Calophyllum brasiliense Cambess.) sob diferentes condições de sombreamento. Revista Brasileira de Biociências, v.14, p.187-192, 2016.

Oliveira, A. K. M. de; Perez, S. C. J. de G. A. e. Crescimento inicial de Tabebuia aurea sob três intensidades luminosas. Ciência Florestal, v.22, p.263-273, 2012. https://doi. org/10.5902/198050985733

Pereira, A. R.; Sediyama, G. C.; Villa Nova, N. A. Evapotranspiração. Campinas: FUNDAG, 2013. 323p.

Santos, C. S. dos; Montenegro, A. A. de A.; Santos, M. A. L. dos; Pedrosa, E. M. R. Evapotranspiration and crop coefficients of Moringa oleifera under semi-arid conditions in Pernambuco. Revista Brasileira de Engenharia Agrícola e Ambiental, v.21, p.840-845, 2017. https://doi.org/10.1590/1807-1929/agriambi. v2 1 n 12 p $840-845$ 
Scalon, S. de P. Q.; Mussury, R. M.; Euzébio, V. L. de M.; Kodama, F. M.; Kissmann, C. Estresse hídrico no metabolismo e crescimento inicial de mudas de mutambo (Guazuma ulmifolia Lam.). Ciência Florestal, v.21, p.655-662, 2011. https://doi.org/10.5902/198050984510

Silva, A. R. A. da; Bezerra, F. M. L.; Freitas, C. A. S. de; Amorim, A. V.; Carvalho, L. C. C. de; Pereira Filho, J. V. Coeficientes de sensibilidade ao déficit hídrico para a cultura do girassol nas condições do semiárido cearense. Revista Brasileira de Agricultura Irrigada, v.8, p.38-53, 2014. https://doi.org/10.7127/rbai.v8n100185

Silva, C. A. da; Dourado Neto, D.; Silva, C. J. da; Melo, B. de. Desenvolvimento de mudas de pitangueira em função de lâminas de irrigação em dois tamanhos de recipiente. Irriga, v.20, p.638651, 2015a. https://doi.org/10.15809/irriga.2015v20n4p638
Silva, C. J. da; Silva, C. A. da; Freitas, C. A. de; Golynski, A.; Golynski, A. A. Produção e crescimento de mudas de baruzeiro em função de recipientes e lâminas de irrigação. Irriga, v.20, p.652-666, 2015 b. https://doi.org/10.15809/irriga.2015v20n4p652

Souza, A. P. de; Mota, L. L. da; Zamadei, T.; Martim, C. C.; Almeida, F. T. de; Paulino, J. Classificação climática e balanço hídrico climatológico no estado de Mato Grosso. Nativa, v.1, p.34-43, 2013. https://doi.org/10.14583/2318-7670.v01n01a07

Souza, A. P. de; Ramos, C. M. C.; Lima, A. D. de; Florentino, H. de O.; Escobedo, J. F. Comparison of methodologies for degreeday estimation using numerical methods. Acta Scientiarum. Agronomy, v.33, p.391-400, 2011. https://doi.org/10.4025/ actasciagron.v33i3.6018 